\title{
Calculating model of the bearing ability of the substructed areas of baltic basalt concrete structures
}

\author{
V. Karpiuk, I. Karpiuk, A. Tselikova, A. Khudobych \\ Odesa State Academy of Building and Architecture, Didrihsona str., Odesa, 65029, Ukraine \\ Corresponding author. E-mail: tselikovaa93@gmail.com \\ ORCID:(0000-0002-4088-6489), ORCID: (0000-0003-3437-5882), ORCID:(0000-0002-1394-3986), \\ ORCID:( 0000-0002-5336-599X) \\ Paper received 17.07.20; Accepted for publication 12.08.20.
}

\section{https://doi.org/10.31174/SEND-NT2020-238VIII29-03}

\begin{abstract}
Non-metallic composite reinforcement (NKA) is increasingly used in modern construction, due to its characteristics such as high strength, resistance to chemical and physical corrosion, low weight and low thermal conductivity, it is increasingly replacing steel reinforcement. The wider use of NKA for reinforcing concrete structures is constrained by insufficient knowledge of the features of their work and limited regulatory support. The regulatory documents of different countries of the world were studied to calculate the bearing capacity of inclined sections of conventional single-span concrete beams reinforced with both steel and basaltplastic reinforcement (BFRP). A comparative analysis of the actual bearing capacity of inclined sections of reinforced concrete beams and basalt-concrete experimental beams with similar structural factors is applied. A comparative analysis of the actual bearing capacity of inclined sections of basalt concrete beams reinforced with BFRP, and its calculated values calculated according to the recommendations of existing design standards of foreign countries, showed their unsatisfactory convergence. Basically, foreign standards underestimate up to several times the real bearing capacity of research beams reinforced with both steel and basalt reinforcement. The bearing capacity of inclined sections of basalt-concrete beams with large $\left(a / h_{0}=3\right)$ and medium $\left(a / h_{0}=2\right)$ section spans should be determined by an inclined crack using variable coefficients $\varphi_{\mathrm{c} 2}, \varphi_{\mathrm{c} 3}, \varphi_{\mathrm{c} 4}$, taking into account the real length of a dangerous inclined crack $l_{c r f 1}^{\prime}$ and a significant reduction in tensile stresses to $(0,10-0,15) f_{f k}$. The bearing capacity of the supporting sections in accordance with small shear spans $a \leq h_{0}$ must be determined as for short cantilevers by the inclined compressed strip between the concentrated force and the support using a variable coefficient $k_{f}$. This approach provides satisfactory convergence $(\mho=7,9 \%)$ of the calculated and experimental values of the bearing capacity of inclined sections of rectangular basalt concrete beams.
\end{abstract}

Keywords: basalt-plastic and steel reinforcement, bearing capacity, deformability, crack resistance, static and low-cycle loads.

Introduction. During recent decades the structures with non-metallic composite reinforcements (NCR) find the ever growing use in the construction practice, particularly in the special purpose buildings and facilities.

Due to high strength, resistance to physical and chemical corrosion, dielectric and diamagnetic properties, little weight and low heat conductivity, the NCR replace steel reinforcement increasingly frequently. However, a wide use of the NCR for reinforcing concrete structures is hindered by insufficient study of the peculiarities of their performance, inadequate regulatory support and scant experience of operating the appropriate facilities.

Experience has shown that the use of NCR is promising and economically justified when constructing roads, hydrotechnical and transport facilities, erection of bridge spans, treatment facilities, chemical installations and food industry facilities as well as special purpose buildings and arrangement of foundations in corrosive soil environment. At that, the application prospects of the basalt plastic reinforcement is explained by low cost of the main raw material - basalt fibre as far as by the fact that in the world there are considerable deposits of basalt which has unique physical and chemical properties, specifically, the better chemical resistance to corrosive environment as compared with the fiber-glass reinforcement.

Proceeding from the above, it is a topical task to perform experimental and theoretical research of the loadbearing capacity of the structures reinforced with basaltplastic in order to accumulate the database and improve the existing and develop new regulatory documents that enable to a wider application of such reinforcement in the indicated spheres of special facility construction.

Analysis of recent sources of research and publications. To calculate the load-bearing capacity of inclined sections of ordinary single-girder concrete beams reinforced with both steel and basalt-plastic reinforcement (BFRP), and to compare them with experimental data, the national design standards were chosen among foreign ones (European EUROCODE - 2 [1], Japanese [2], American ACICODE [3], Canadian CSA [4], Italian CNR [5]), which presented methods for calculating the load-bearing capacity of concrete beam structures reinforced with NCA.

Methods for calculating the strength of supporting sections of girder structures reinforced with steel and nonmetallic composite reinforcement (NCA), national design standards of different countries, in addition to the wellknown method of limiting forces in SNiP 2.03.01 - 84 *, are based on the classical model of truss analogy W. Ritter - E Morsh and its various modifications, arched analogy or a combination of truss and arched analogy. All the above rules, including the previously valid domestic SNiP provide for a separate calculation of inclined sections on the action of transverse forces and normal sections on the action of bending moments.

Highlighting previously unresolved parts of the overall problem. The priority of research and publications on this topic in recent years is the development of the regulatory framework in the field of building structures and the introduction of the deformation method for calculating their bearing capacity. In addition, if the study of the load-bearing capacity of normal sections is devoted to numerous works of domestic and foreign researchers, the load-bearing capacity of inclined sections of beam elements remains insufficiently studied.

When designing real structures with NCA in the calculations for the first group of limit states, the design characteristics of materials and design forces are used. In 
order to determine the destructive forces and verify the calculation formulas of national design standards, they use the characteristic values of the strength of concrete and basalt-plastic reinforcement (BFRP).

The basic principles of calculation of bent structures reinforced with NCA in all foreign norms and domestic guidelines [6] are preserved the same as for elements with steel reinforcement.

Purpose and objectives of research. This work is aimed at experimental study of strength, crack resistance and stress-strain behavior of the BFRP concrete beams and establishment of the appropriate databank for further development of the physical and mathematical models of the bearing capacity of the normal and transverse crosssections of the BFRP spanned concrete structures with due account of the action of static and low-cycle high level loads by analogy to similar models [0-0], that have been developed for the reinforced concrete structures.

Methods of conducting experiments, materials and equipment. In connection with the above, the system experimental research [0-0] of the load-bearing capacity of support zones of complex loaded reinforced concrete beam structures are being performed in Odesa State Academy of Construction and Architecture.

To achieve this goal two more series of field studies were additionally accomplished by testing single-span BFRP concrete beams subjected to static and low-cycle repeated loads of high level in accordance with the central government budget research projects (state registration Nos.0107U000809 and 0108U000559) with the use of the experimental design theory and efficient PC software COMPEX of Prof. V.A. Voznesenskyi.

It is known from literary sources that the main performance parameters of steel, fibre and basalt fibre reinforced concrete structures are governed by the Gaussian law and that it is possible to process the results with the least square method. As the studied factors can influence the output function in a non-linear manner, it is expedient to approximate it with the second order polynomial. That is why the test samples were prepared with the use of the three-factor three-level D-optimum Box plan B3 [0], which ensures the same accuracy of the output parameter prediction within the area that is described with the radius that equals the conventional " 1 " with respect of the "zero" point.

The following factors (design factors) were chosen as the test ones that were changing at three levels: $X_{1}-$ relative shear span (distance from the support to the concentrated force), $a / h_{0}=1,2,3$ at $h_{0}=\mathrm{d}=175 \mathrm{~mm} ; X_{2}-$ the concrete grade $\mathrm{C}, \mathrm{MPa}, \mathrm{C} 16 / 20, \mathrm{C} 30 / 35, \mathrm{C} 40 / 50 ; X_{3}-$ transverse reinforcement coefficient $\rho_{f w}$ (ACB-800 (composite basalt-plastic reinforcement)) $=0.0029$; $0.0065 ; 0.0115$ for basalt fibre reinforced concrete beams and $\rho_{s w}(\mathrm{BpI})=0.0016 ; 0.0028 ; 0.0044$ for the reinforced concrete samples. Coefficients of the upper and low longitudinal reinforcement $\rho_{l f}=\rho_{l s}=0.0176$ for both beam types with the design spans $L_{0}=9 h_{0}=1,575 \mathrm{~mm}$ and width $\mathrm{b}=100 \mathrm{~mm}$.

Each study of the field test provided for two twin beams having four support areas. Altogether there were tested $30+30=60$ basalt concrete beams subjected to, accordingly, stepped increase of the static and low-cycle repeated loading. For the sake of comparison, we used the test results of similar reinforced concrete beams [0].

The tested beams were reinforced with basalt fibre plastic in kind of two flat tied frames. These elements were produced with the use of heavy concrete of the above indicated grades plus the $5-10 \mathrm{~mm}$ granite chips and $1.5 \mathrm{~mm}$ fineness modulus quartz sand. Portland cement grade 500 without additives was used as a binder. In order to reduce the water/cement ratio, make it more convenient to place concrete mix and shorten the cure period, all tests were conducted with Relaxol-Super M (ISO 9001 № 04.156.26) complex additive in quantity of $1 \%$ of the cement weight as recalculated to dry substance.

Special power installations were designed, manufactured and certified for testing the sample beams. Loads were applied according to the four-point scheme with the aid of the DG-50 hydraulic jack and the load distribution traverse beam; the concentrated forces were applied in stages: with the step $(0.04 \ldots 0.06) F_{u l t}$ untilappearance of the first normal and inclined cracks, and afterwards with the step $(0.08 \ldots 0.12) F_{u l t}$ until rupture. The time exposure on a step was up to 15 minutes, and all measurements were made at the beginning and at the end of each step.

Before making the test beams, chains of KF5P1-5-200 strain gauges were glued on the tensioned reinforcement of one of the flat frames (base $5 \mathrm{~mm}$ ) in compliance with the technology recommended by the manufacturer (LLC "Veda", Kyiv).

Deformation of the test concrete samples were measured with the aid of wire and foil strain gauges with the 40 and $50 \mathrm{~mm}$ base according to the generally adopted methodology; the strain gauges were glued on one lateral and the top polished sides. The transfer from the strains of the reinforcement measured during testing was accomplished according to Hooke law, and the strains in the concrete were measured through the sectional elasticity modulus. Deformations of the concrete located in the compressed zone and in the tensioned reinforcement were checked with the aid of the dial gauges and the vertical displacements were measured with deflection indicators.

Presentation of the main material and results. It is recommended to determine the bearing capacity of structures with non - metallic composite reinforcement under the action of static loading by the deformation or deformation - force model. In this case, the forces and deformations in the normal cross section can be determined in accordance with the prerequisites of paragraph 6.1 of DBN B.2.6 - 98 [11], taking the relationship between stresses and strains in composite reinforcement linear according to existing recommendations in the normative and reference technical literature.

The calculated resistance of composite reinforcement located in the compressed zone of the concrete structure is recommended to be taken according to $[0] f_{c d}=0,2 f_{c d}$.

The calculations allow the use of simplified dependences "Stress - strain" for concrete and the uniform nature of the distribution of normal compressive stresses in the compressed zone in accordance with p. 3.1.7.1 and 3.1.7.2 DBN B.2.6 - 98 [11].

For weakly reinforced concrete structures, in which the bearing capacity of normal sections may be less than the moment of crack formation, it is recommended to increase the area of non-metallic composite reinforcement 
so that their bearing capacity is 1.5 times higher than the moment of formation of normal cracks.

It is recommended to use non-metallic composite reinforcement, first of all, as longitudinal reinforcement in constructions in which transverse reinforcement is optional by calculation. In this case, the longitudinal stretched NCA must accept the additional tensile force caused by the shear, in accordance with paragraph 4.6.3.8 of DSTU B B.2.6 - 156 [12].

In solid, ribbed or hollow slabs with NCA, in which the redistribution of transverse loads is possible, the transverse reinforcement may not be installed with the appropriate justification.

In rod, including beam, structures with NCA, which do not require the calculated transverse reinforcement, the authors [6] recommend to install structural transverse steel reinforcement, the minimum number of which is recommended to determine the formula:

$$
\rho_{w, \text { min }}=\frac{0,08 \sqrt{f_{c k}}}{f_{y k}},
$$

where $f_{c k}$ - characteristic value of concrete compressive strength, MPa;

$f_{y k}$ - characteristic value of tensile strength of steel reinforcement on the yield point, MPa.

In elements with longitudinal non-metallic composite reinforcement, which require the calculated transverse reinforcement, the authors [6] recommend to take as a transverse steel reinforcement in accordance with DSTU 3760 and GOST 5781.

To calculate the load-bearing capacity of the supporting sections of bending elements that require calculated transverse reinforcement, along with the general mechanics of concrete reinforced with steel or non-metallic composite reinforcement, deformation or deformation-force model, it is recommended to use the best experimental design. previously valid domestic SNiP 2.03.01 - $84 *$ [13] taking into account the adjustments that are proposed to be made to it based on the results of recent experimental - theoretical studies.

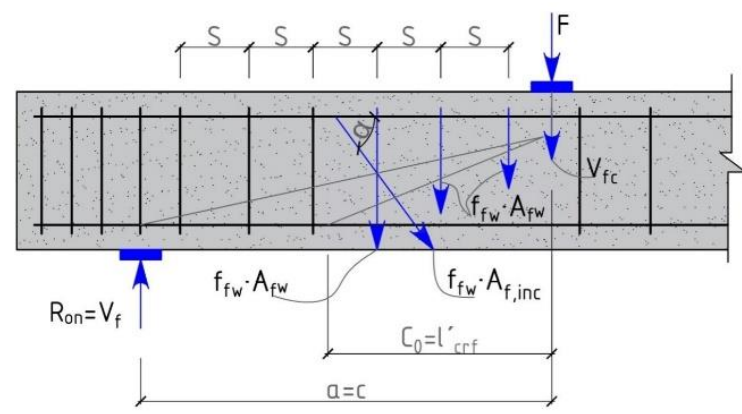

Fig. 1.1. Calculation scheme of the supporting section of the basalt concrete element when calculating its bearing capacity under the action of transverse force.

Taking into account the recommendations of p.3.31 $\mathrm{SNiP}$ [13], the calculation of concrete beams reinforced in sufficient quantities $\quad \rho_{f w} \geq 0,0025, \rho_{l f} \geq 0,0100$ basaltoplastic reinforcement BFRP (Fig. 1.1), on the combined action of transverse force and bending moment to ensure their load-bearing capacity and inclined crack must be carried out on the most dangerous inclined section, provided:

$$
V_{f} \leq V_{f c}+V_{f w}+V_{f, i n c}
$$

where $V_{f c}, V_{f w}$ i $V_{f, i n c^{-}}$components of transverse force, which are perceived, respectively, by concrete, transverse reinforcement and bends.

The transverse force $V_{f}$ in condition (1.2) is determined from the external load located on one side of the inclined section under consideration.

The component of the transverse force, which is perceived by the concrete of the compressed zone is determined by the formula:

$$
V_{f c}=\frac{\varphi_{c 2}\left(1+\varphi_{f}+\varphi_{n}\right) f_{c t d} \cdot b_{w} \cdot d^{2}}{a},
$$

where $a=c-$ the length of the projection of the most dangerous inclined section on the longitudinal axis of the element (span of the section);

$\varphi_{c 2}-$ a coefficient that comprehensively takes into account the influence of the shear span, the concrete class and the number of BFRP transverse reinforcement. This coefficient, in contrast to its prototype $\varphi_{b 2}=2$ in $\mathrm{SNiP}$ [13] for heavy concrete, differentiates the effect of structural factors on the value of $V_{f c} \cdot$ Коефіцієнт $\varphi_{c 2}$ is obtained experimentally from the inverse. That is, having experimentally established adequate values of the projection length of the dangerous inclined crack $l_{c r f}^{\prime}=C_{0}$ (experimental-statistical dependence (1.4), coefficient of variation $\mho=5,4 \%$, as well as confirmed by direct measurements of deformation $\varepsilon_{f w}$ and simulation of VAT stress $\sigma_{f w}$ transverse reinforcement, the reliable values of the components $V_{f w}$ were determined. And the components $V_{f c}=V_{f}-V_{f w}$. In this case, $V_{f, i n c}=0$, because the bends in the beams were absent.

$$
\begin{array}{r}
\hat{\mathrm{Y}}\left(l_{c r f 1}^{\prime}\right)=176+25 \mathrm{x}_{1}+9 \mathrm{x}_{2}-16 \mathrm{x}_{3}-9 x_{1}^{2}+8 x_{2}^{2} \\
-9 x_{3}^{2}-9 \mathrm{x}_{1} \mathrm{x}_{3}, \mathrm{MM}, \mho=5,4 \%
\end{array}
$$

The experimental-statistical dependence of the coefficient $\varphi_{c 2}$ has the form:

$$
\begin{gathered}
\hat{Y}\left(\varphi_{c 2}\right)=1,38-0,25 X_{1}-0,12 X_{2}-0,22 X_{1} X_{3}, \mho \\
=5,2 \%,
\end{gathered}
$$

which after replacing the coded variables with natural values of design factors is converted into the form:

$$
\begin{aligned}
\varphi_{\mathrm{c} 2}=1,38-0,25 & \left(a / h_{0}-2\right)-0,12\left(\frac{C-35 \text { МПа }}{15 \text { МПа }}\right) \\
& -0,22\left(a / h_{0}\right. \\
& -2)\left(\frac{\rho_{f w}-0,0072}{0,0043}\right) .
\end{aligned}
$$

Given the allowable extrapolation of the results obtained, the dependence (1.6) is valid when changing design factors within the following limits:

the magnitude of the relative span of the $\operatorname{slice}^{a} / h_{0}=1,0-3,3$

- $\quad$ concrete class in MPa fromC12/15 до C45/55;

- coefficient of transverse reinforcement $\rho_{f w}=$ $0,0018-0,0126$.

The geometric interpretation of the influence of these constructive factors on the value of the coefficient $\varphi_{c 2}$ is presented in Fig. 1.2.

The coefficient $\varphi_{f}$, which takes into account the influence of compressed shelves on the load-bearing capacity of inclined sections of T-shaped and I-beam elements, is taken in the wording of SNiP 2.03.01-84* [13] and is determined by the formula: 


$$
\varphi_{f}=0,75 \frac{\left(b_{f}^{\prime}-b\right) h_{f}^{\prime}}{b \cdot h_{0}} \leq 0,5
$$

In this case, $b_{f}^{\prime}$ is taken as a value that does not exceed the value of $b+3 h_{f}^{\prime}$, and the transverse reinforcement must be anchored in the shelf.

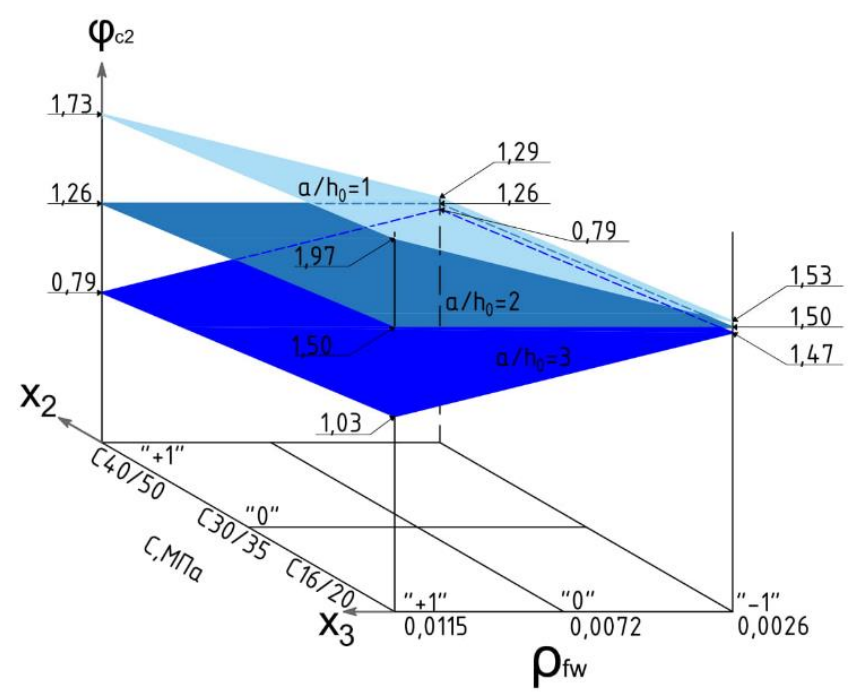

Fig. 1.2. Complex influence of structural factors on the value of the coefficient $\varphi_{c 2}$ of beam structures with small $\left(a / h_{0}=\right.$ $1)$, medium $\left(a / h_{0}=2\right)$ and large $\left(a / h_{0}=3\right)$ spans of the cut.

The coefficient $\varphi_{n}$, which takes into account the influence of longitudinal forces on the bearing capacity of inclined sections of deflection structures, is also accepted in the edition of SNiP [13] and is determined by the formula:

$$
\varphi_{n}=0,1 \frac{N}{f_{c t d} \cdot b \cdot h_{0}} \leq 0,5
$$

In prestressed elements in formula (1.8) instead of $N$ the force of pre-compression of concrete $P$ is used taking into account all possible losses. In this case, the positive effect of longitudinal compressive forces is not taken into account if they create bending moments that are identical in signs with the bending moments from the action of the transverse load.

Under the action of longitudinal tensile forces, formula (1.8) is transformed into the form:

$$
\begin{gathered}
l_{c r f 1}^{\prime}=\left[176+25\left(a / h_{0}-2\right)+9\left(\frac{C-35 M P a}{15 M P a}\right)-16\left(\frac{\rho_{f w}-0,0072}{0,0043}\right)-9\left(a / h_{0}-2\right)^{2}+8\left(\frac{C-35 M P a}{15 M P a}\right)^{2}-\right. \\
\left.9\left(\frac{\rho_{f w}-0,0072}{0,0043}\right)^{2}-9\left(a / h_{0}-2\right)\left(\frac{\rho_{f w}-0,0072}{0,0043}\right)\right] m m, \mho=5,4 \% .
\end{gathered}
$$

Dependence (1.12) is valid when the constructive factors change within the limits specified for expression (1.6).

The force in the transverse reinforcement $V_{f w}$ is traditionally determined by the formula:

$$
V_{f w}=q_{f w} \cdot l_{c r f 1}^{\prime} \text {, }
$$

where $q_{f w}$ - the force in the transverse rods (clamps) per unit length of the element, ie the intensity of the transverse reinforcement, is determined by the formula:

$$
q_{f w}=\frac{\sigma_{f w} \cdot A_{f w}}{s}
$$

where $\sigma_{f w}-$ stresses in the rods of the transverse composite reinforcement, which intersect with a dangerous inclined crack. According to full-scale measurements of deformations and modeling of the stress-strain state in the transverse rods of beam structures with large shear spans $\left(a / h_{0}=3\right)$ it is recommended to take $\sigma_{f w}=0,1 f_{f k}$, and

$$
\varphi_{n}=-0,2 \frac{N}{f_{c t d} \cdot b \cdot h_{0}}
$$

$\leq 0,8$ за абсолютною величиною.

The total value of the increasing coefficients $(1+$ $\left.\varphi_{f}+\varphi_{n}\right)$ is recommended to be taken not to exceed 1.5 at this stage of research.

The value of $V_{f c}$, calculated by formula (1.3), by analogy with SNiP 2.03.01-84 [13] should be taken not less than the value:

$$
\varphi_{c f} \geq \varphi_{c 3}\left(1+\varphi_{f}+\varphi_{n}\right) f_{c t d} \cdot b \cdot h_{0}
$$

In this case, the value of the coefficient $\varphi_{c 3}$ for heavy concrete must be reduced by the formula:

$$
\varphi_{c 3}=\frac{\varphi_{c 2} \cdot \varphi_{b 3}}{\varphi_{b 2}} .
$$

where $\varphi_{b 2}, \varphi_{b 3}$ - are the coefficients from SNiP 2.03.01-84*, which for heavy concrete are equal to 2.0 and 0.6 , respectively.

Transverse forces $V_{f w}$ and $V_{f, i n c}$, which are perceived, respectively, by the transverse reinforcement and bends, which are crossed by a dangerous inclined crack.

The length $C_{0}$ of the projection of a dangerous inclined crack on the longitudinal axis of the element $\mathrm{SNiP}$ 2.03.01-84* [13] recommends determining the minimum expression $Q_{b}+Q_{s w}+Q_{s, i n c}$, in which when calculating $Q_{b}$ instead of the length of the slice $a=c$ is used $C_{0}$. The value of $C_{0}$ obtained in this way according to $\mathrm{SNiP}$ 2.03.01-84* [13] should have come not greater than the value of $2 h_{0}$ and not more than the value of $C$, as well as not less than the value of $h_{0}$, if $C>h_{0}$.

However, numerous field experiments have revealed a significant discrepancy between the experimental and calculated by SNiP 2.03.01-84* values of $C_{0}$, which calls into question the feasibility of such an approach, including the adoption of $Q_{s w}=Q_{b}$.

Based on the above and taking into account the available research data, the projection length of the dangerous inclined crack $l_{c r f 1}^{\prime}$ in concrete elements reinforced with composite reinforcement, including BFRP, with their static load (series 1) is recommended to determine the experimental-statistical dependence (1.4), which after replacing the coded variables with natural has the form: in elements with medium shear spans $\left(a / h_{0}=2\right)-$ $\sigma_{f w}=0,15 f_{f k}$. In this case, when used as a transverse reinforcement BFRP relative deformations $\varepsilon_{f w}$ in it before the destruction of the experimental beams were, respectively, 0,0018 i 0,0028. These data are in good agreement with the recommendations of fib [14] to limit the relative deformation of the transverse NCA of $0,20-$ $0,25 \%$.

In beam elements with small shear spans $\left(a / h_{0} \geq 1\right)$, direct measurements and modeling of VAT showed that compressive stresses occur in the rods of vertical transverse reinforcement, the average value of which in beams with BFRP reached $-363 M P a \approx-0,45 f_{f k}$. In this case, $\varepsilon_{f w}=-0,0084$. It is obvious that in such elements there is almost the same probability of destruction of their supporting sections both from the cut of concrete behind an 
inclined crack $\left(\max \tau_{c x z} \leq f_{c k} / 2\right)$ and behind an inclined compressed strip $\left(\max \sigma_{c z}=(1,0-1,5) f_{c k}\right)$.

But, given the fact that the height of the compressed zone of concrete under the concentrated force $F$ applied at the end of the span of the cut, artificially decreases (by $25 \%$ or more), still, there is a probability of destruction of these areas according to the calculation scheme. 1.1 with a section of concrete over the top of the dangerous inclined crack and without taking into account the operation of the transverse inclined crack and without taking into account the operation of the transverse reinforcement on them, so $\sigma_{f w}=0$ for $a / h_{0} \approx 1$.

$A_{f w}$ - the cross-sectional area of the cross bars or clamps in one cross-sectional plane of the element.

The transverse force perceived by the bends,

$$
V_{f, i n c}=q_{f w, i n c} \cdot l_{c r f 1} \text {. , }
$$

When determining $q_{f w, i n c}$ it is necessary to take into account the angles of inclination $\alpha$ and it is allowed to take the voltage in them $\sigma_{f}=0,25 f_{f k}$ with $\varepsilon_{f, i n c}=$ 0,0045 according to the recommendation of fib [14] and provided reliable anchoring of bends on supports and and spans the element.

According to comparative calculations in beam structures with large and medium spans, in which the transverse reinforcement is installed by calculation, the condition must be met:

$$
q_{f w} \geq \frac{\varphi_{c 3}\left(1+\varphi_{f}+\varphi_{n}\right) \cdot f_{c t d} \cdot b}{3},
$$

as well as the relevant design requirements.

The calculation of concrete elements reinforced with longitudinal NCA without transverse rods and clamps, on the combined action of transverse forces and bending elements in order to ensure their load-bearing capacity by inclined crack by analogy with SNiP 2.03.01-84* [13] is recommended to perform the most dangerous cross section conditions:

$$
V_{f}=\frac{\varphi_{c 4}\left(1+\varphi_{n}\right) f_{c t d} b \cdot d^{2}}{\alpha^{\prime}}
$$

in which the right part is taken as a smaller value of $2,5 f_{c t d} \cdot b \cdot d$ and not less

$$
\varphi_{c 3}\left(1+\varphi_{n}\right) f_{c t d} \cdot b \cdot d \text {. }
$$

The coefficient $\varphi_{\mathrm{c} 4}$ is recommended to be determined taking into account its reduction compared to the coefficient $\varphi_{b 4}$ with SNiP 2.03.01-84* [13] by the formula:

$$
\varphi_{c 4}=\frac{\varphi_{c 2}}{\varphi_{b 2}} \varphi_{b 4} \text {. }
$$

For heavy concrete $\varphi_{b 4}=1,5$.

The comparison of experimental data and calculated values of bearing capacity of inclined sections $V_{u f}^{*}$ according to the calculated model SNiP 2.03.01-84* adapted to concrete elements reinforced by NCA [13] shows in general, their satisfactory convergence $(\mho=$ $11 \%$ ). The largest differences between the experimental and calculated values of $V_{u f}^{*}$ were observed in basaltconcrete beams with small spans. To improve the convergence of experimental and predicted values of the bearing capacity of the supporting sections of the beams with small spans $\left(a \leq h_{0}\right)$, calculate it according to the recommendations of SNiP 2.03.01-84* [13] according to the scheme of short consoles, transformed in our case to the form (Fig.1.3 ). The validity of this approach is confirmed by the results of field experiments using distribution plates with width $l_{\text {sup }}$ under concentrated forces and on supports, resulting in artificial reduction of the shear span, as well as the results of modeling VAT of concrete and transverse reinforcement, which in all beams with such shear spans deformed.

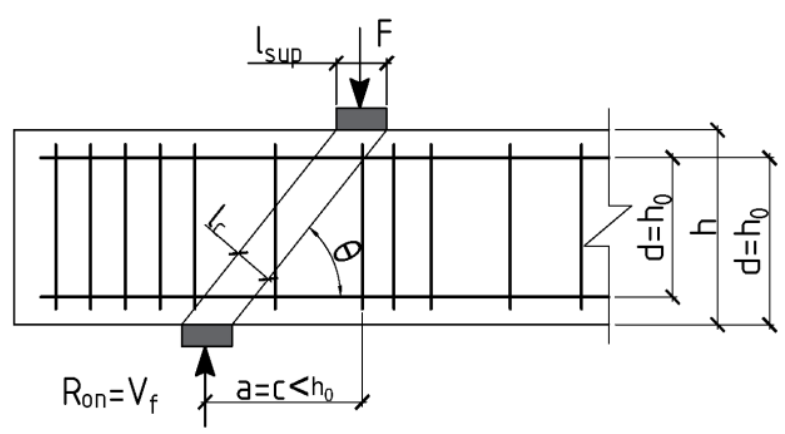

Fig.1.3. The calculated scheme of bearing capacity of the supporting section of the basalt concrete beam with a small span of the cut $\left(a<h_{0}\right)$ on an inclined compressed strip between the concentrated force and the support.

The bearing capacity of the inclined strip of the specified element is determined by the condition:

$V_{f} \approx F \leq k_{f} \cdot \varphi_{w 2} \cdot f_{c d} \cdot b \cdot l_{c} \cdot \sin \theta \leq 3,5 f_{c t d} \cdot b \cdot h_{0}$,

$k_{f} \cdot \varphi_{w 2} \cdot f_{c d} \cdot b \cdot l_{c} \cdot \sin \theta \geq \frac{\varphi_{c 4}\left(1+\varphi_{n}\right) f_{c t d} \cdot b \cdot d^{2}}{a}$

where $\theta$-the angle of inclination of the calculated compression strip to the horizontal;

$l_{c}-$ the width of the calculated compression band, which is determined by the formula:

$$
l_{c}=l_{\text {sup }} \cdot \sin \theta \text {, }
$$

where $l_{\text {sup }}$ - the length of the load transfer site along the span of the beam;

$\varphi_{w 2}-$ a coefficient that takes into account the influence of transverse rods or clamps, if any, on the height of the beam and is determined by the formula:

$$
\begin{array}{r}
\varphi_{w 2}=1+5 \alpha \cdot \mu_{w 1}, \\
\text { where } \alpha=E_{f} / E_{c} ; \mu_{w 1}=\frac{A_{f w}}{b \cdot S_{w}} ;
\end{array}
$$

$A_{f w}$ - the cross-sectional area of the clamps in one horizontal plane (if any);

$S_{w}$ - the distance between the said clamps (if any) on the normal to them. In this case, horizontal clamps and inclined at an angle of not more than $45^{\circ}$ to the horizontal in compliance with well-known requirements are taken into account.

For the presented constructions of basalt concrete beams the coefficient $\varphi_{w 2}=1+0=1$.

The coefficient $k_{f}$ in the old SNiP 2.03.01-84* [13] is recommended to be constant and equal to 0.8 . For basaltconcrete beams with a short span of the cut and short consoles $a<h_{0}$ in the opposite way, the experimental value of $k_{f}$ was found in experiments by the formula:

$$
k_{f}=V_{u f} /\left(\varphi_{w 2} \cdot f_{c k} \cdot b \cdot l_{c} \cdot \sin \theta\right)
$$

subject to conditions (1.20).

Processing of the obtained values of the coefficient $k_{f}$ allowed to obtain an adequate experimental - statistical dependence for these elements:

$$
\begin{gathered}
\hat{Y}\left(k_{f}\right)=1,67-0,25 X_{2}-0,21 X_{3}-0,08 X_{2} X_{3}, \mho \\
=2,5 \%,
\end{gathered}
$$

replacement of coded variables, in which the natural values of structural factors in the field experiment allows to obtain an empirical formula for determining the coeffi- 
cient $k_{f}$ taking into account the change of concrete class from $\mathrm{C} 12$ / 15 to $\mathrm{C} 45$ / 55 and the coefficient of transverse reinforcement within $\left.\left(\rho_{f w}=0,0018-0,0126\right)\right)$ :

$$
\begin{aligned}
& k_{f} \\
& =1,67-0,25\left(\frac{\mathrm{C}-35 \mathrm{M} \Pi \mathrm{a}}{15 \mathrm{M} П \mathrm{a}}\right)+0,21\left(\frac{\rho_{f w}-0,0072}{0,0043}\right) \\
& -0,08\left(\frac{\mathrm{C}-35 \mathrm{MПа}}{15 \mathrm{MПа}}\right)\left(\frac{\rho_{f w}-0,0072}{0,0043}\right) \text {. }
\end{aligned}
$$

Geometric interpretation of the dependence of the coefficient $k_{f}$ on the ratio of design factors is presented in Fig. 1.4 .

The application of the experimentally established coefficient $\varphi_{-} \mathrm{c} 2$ for basalt concrete beams with large $\left(a / h_{0}=\right.$ $3)$ and medium $\left(a / h_{0}=2\right)$, as well as the coefficient $k_{f}$ in elements with small $\left(a / h_{0}=1\right)$ spans allowed to approximate the experimental and the above formulas the value of the bearing capacity of their supporting sections to satisfactory limits $(\mho=7,9 \%)$.

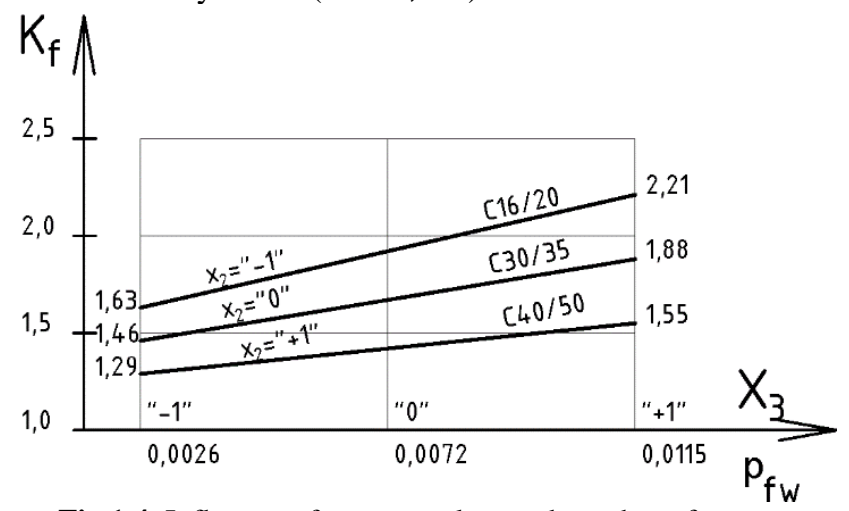

Fig.1.4. Influence of concrete class and number of transverse reinforcement on the value of the variable coefficient $k_{f}$ in formula (1.20).

The calculation of concrete T-shaped and I-beam concrete beams reinforced with basalt-plastic reinforcement, with the combined action of transverse force and bending moment is performed to ensure the strength of inclined strips between inclined cracks in their walls on the supporting sections of the condition:

$$
V_{f} \approx F \leq 0,3 \varphi_{w 1} \cdot \varphi_{c 1} \cdot f_{c d} \cdot b_{w} \cdot d,
$$

where $\varphi_{w 1}-$ a coefficient that takes into account the influence of normal to the longitudinal axis of the transverse rods or clamps on the bearing capacity of the supporting sections of these beams. It is recommended to determine by formula (1.22) and take no more than 1.1;

$b_{w}$ - wall thickness of T-shaped or I-beam sections.

The coefficient $\varphi_{\mathrm{c} 1}$ is recommended to be determined by the method of SNiP 2.03.01-84* [13] with the adjusted value of the coefficient $\beta^{*}$ :

$$
\begin{aligned}
& \varphi_{\mathrm{c} 1}=1-\beta^{*} \cdot f_{c d}, \\
& \text { where } \beta^{*}=\frac{\varphi_{c 2} \beta}{\varphi_{b 2}},
\end{aligned}
$$

$\varphi_{b 2}$ and $\beta$ - coefficient with $\mathrm{SNiP} 2.03 .01-84 *$, which for heavy concrete are, respectively, 2 and 0.01 .

\section{Conclusions:}

1. Comparative analysis of the actual load-bearing capacity of inclined sections of reinforced concrete experimental beams (series ASD) with similar design factors and the use of metal longitudinal and transverse reinforcement instead of basalt-plastic and its calculated values according to SNiP 2.03.01-84* [13] and current in Ukraine Eurocode [1] in the form of DSTU BV.2.6 - 156: 2010 [12] showed that the previously existing domestic SNiP [13] shows a much better convergence (coefficient of variation $\mho=17,5 \%)$ compared to Eurocode 2 [1] $(\mho=64,4 \%)$ because they are better than European and other, as previous studies have shown, foreign standards reflect the physical picture of the experimental beams under load.

2. A comparison of the actual load-bearing capacity of inclined sections of basalt-concrete beams reinforced with BFRP and its calculated values, calculated according to the recommendations of the existing national design standards of foreign countries, also showed their unsatisfactory convergence. Thus, the coefficient of variation for Eurocode 2 [1] is $\mho=85,2 \%$, Japanese standards JSCE [2] - $\mho=77,9 \%$, American ACI [3] - $\mho=81,7 \%$, Canadian CSA [4] $-\mho=61,1 \%$, Italian CNR [5] - $\mho=59 \%$. In general, these standards underestimate several times the actual load-bearing capacity of experimental beams reinforced with both steel and basalt reinforcement. This comparison showed that the best convergence of these values is characteristic of those norms that are not based on a modified truss analogy or modified compression field theory, but on experimentally validated calculation schemes that better reflect the physical picture of experimental elements under load.

3.The load-bearing capacity of inclined sections of basalt concrete beams with large $\left(a / h_{0}=3\right)$ and medium $\left(a / h_{0}=2\right)$ spans of the section should be determined by an inclined crack with a predominant action of transverse force using variable coefficients $\varphi_{\mathrm{c} 2}, \varphi_{\mathrm{c} 3}, \varphi_{\mathrm{c} 4}$, taking into account real inclined crack $l_{c r f 1}^{\prime}$ and a significant reduction in tensile stresses (up to $\left.(0,10-0,15) f_{f k}\right)$ in the transverse reinforcement BFRP. The bearing capacity of the support sections of the experimental elements with small shear spans $\left(a \leq h_{0}\right)$ should be determined as for short consoles on an inclined compressed band between the concentrated force and the support using a variable coefficient $k_{f}$. This approach provides satisfactory convergence $(\mho=7,9 \%)$ of the calculated and experimental values of the bearing capacity of inclined sections of basalt concrete beams of rectangular cross section.

\section{ЛІТЕРАТУРА}

1. EN 1992-1-1:2004, Eurocode 2 - Design of Concrete Structures. Part 1: General rules and rules, CEN, 2004. -225 p.

2. JSCE, Recommendation for Design and Construction of Concrete Structures Using Continuous Fiber Reinforcing Materials. Tokyo, Japan: Japan Society of Civil Engineers, 1997.

3. ACI 440.1R-03, Guide for the Design and Construction of Concrete Reinforced with FRP Bars, American Concrete Institute, 2003.

4. CAN/CSA-S6-00, Canadian High Bridge Design Code, Cana- dian Standards Association, 2019.

5. CNR-DT 203/2006, Guide for the Design and Construction of Concrete Structures Reinforced with Fiber-Reinforced Polymer Bars, Rome, Italy, 2006.

6. Настанова 3 проектування та виготовлення бетонних конструкцій 3 неметалевою композитною арматурою на основі базальто- і скло- ровінгу: ДСТУ-Н Б В.2.6185:2012 - [Чиний від 2013-04-01] - Київ.: Міністерство регіонального розвитку, будівництва та житлово- 
комунального господарства України, 2012. - 28 с. (Національний стандарт України).

7. Karpiuk, V.M., Somina, Y.A., Antonova, D.V. calculation models of the bearing capacity of span reinforced concrete structure support zones, vol, 968 MSF, 2019.

8. Karpiuk, V., Somina, Y., Maistrenko, O., Engineering Method of Calculation of Beam Structures Inclined Sections Based on the Fatigue fracture Model. Lecture Notes in Civil Engineering 47, 2020, p. $135-144$.

9. Карпюк B.M. та ін. особливості напружено деформованого стану i розрахунку залізобетонних конструкцій за дії циклічного навантаження високих рівнів: монографія / Карпюк В.М., Сьоміна Ю.А., Костюк А.І., Майстренко О.Ф. - Одеса: ОДАБА, 2018. - 237с.: іл. ISBN 978 - 617- 7195- 54 - 1 .

10. Вознесенский В.А. Статистические методы планирова- ния эксперимента в технико - экономических исследованиях / В.А. Вознесенский [2 - е изд. испр. и доп.] - М.: Финансы и статистика, 1981. $-215 \mathrm{c}$.

11. ДБНВ.2.6-98:2009. Бетонні та залізобетонні конструкції. Основні положення. [Чинний від 2011-06-01]. Київ: Мінрегіонбуд України, 2011. - 71с.

12. ДСТУ Б В.2.6-156:2010. Бетонні та залізобетонні конструкції з важкого бетону. Правила проектування. [Чинний від 2011-06-01]. - Київ: Мінрегіонбуд України, 2011. - $123 \mathrm{c}$.

13. СНиП 2.03.01 - 84* Бетонные и железобетонные конструкции / Госстрой СССР - М.: ЦИТП Госстроя СССР, 1989. - 80c.

FIB Bulletin 40: FRP reinforcement in RC structures. - International Federation for Structural Concrete, 2007.

\section{REFERENCES}

6. Reglament po proektirovaniju i izgotovleniju betonnih konstrukcij s nemetallicheskoj kompozitnoj armaturoj na osnove bazalto- i steklo- roving: DSTU-N V.2.6-185:2012 [Regulation on the design and manufacture of concrete structures with non-metallic composite reinforcement based on basalt and glass roving: DSTU-N B V.2.6-185: 2012] [Actual form 2013-04-01] - Kiev: Ministry of Regional Development, Construction Housing and Communal Services of Ukraine, 2012. - 28 c. (In Ukrainian)

7. Karpiuk, V.M., Somina, Y.A., Antonova, D.V. Calculation models of the bearing capacity of span reinforced concrete structure support zones, Vol. 968 MSF, 2019, p. $209-226$.

8. Karpiuk, V., Somina, Y., Maistrenko, O., Engineering Method of Calculation of Beam Structures Inclined Sections Based on the Fatigue fracture Model. Lecture Notes in Civil Engineering 47, 2020, p. $135-144$.

9. Karpiuk, V.M. and others Osobennosti napryagonnodeformirovannogo sostoyanija i rascheta gelezobetonnih konstrukcij privozdejstivii ciklicheskih nagruzok visokih urovnej: monografija / Karpiuk, V.M., Somina, Y, Kostiuk A.I., Majstrenko O.F. [Features of the stress-strain state and calculation of reinforced concrete structures under the influence of cyclic loads of high levels: monograph] - Odesa, OSABA, 2018. - 237 c. ISBN 978 - 617- 7195- 54 - 1. (In Ukrainian)

10. Voznesenkij V.A. Statisticheskije metodi planirovanija eksperimenta vtehniko-ekonomicheskih issledovanijah / V.A. Voznesenskij [Statistical methods for designing an experiment in technical and economic research] Vol. 2 edited. - M.: Finances and statistics, 1981. - p. 215 (In Russian)

11. GBR B.2.6-98:2009. Betonnije ta zhelezobetonnije konstrikciji. Osnovni polozhennya, [Concrete and reinforced concrete structures. Substantive provisions.] [Actual from 2011-06-01], Kiev, Minregionbuild of Ukraine, 2011. - p. 71

12. GSU B V.2..6-156:2010. Betonnije I zhelezobetonnije konstrukciji iz tyazhelogo betona. [Concrete and reinforced concrete structures made of heavy concrete.] Design rules. [Actual from 2011-06-01] - Kiev: Minregionbuild of Ukraine, 2011.- p. 123 (In Ukrainian).

13. SNiP 2.03.01-84* Betonnije i zhelezobetonnije konstrukciji [Concrete and reinforced concrete structures]/ Govbuild USSR - M.: CITP Govbuil, USSR, 1989. - p. 80. (In Russian)

14. FIB Bulletin 40: FRP reinforcement in RC structures. International Federation for Structural Concrete, 2007. 